\title{
REVIEW
}

\section{elite sociologists and the sociology of elites}

\author{
stephanie lee mudge \\ University of California-Davis, Sociology Department, One Shields Avenue, Davis, \\ CA 95616 USA \\ E-mail: mudge@ucdavis.edu
}

doi: $10.1057 /$ eps. 2009.28

Books reviewed:

Political Interventions: Social Science and Political Action

Bourdieu, Pierre (London and New York: Verso, 2008 (2002)), 398 pp., ISBN: 978 1844671908

European Integration as an Elite Process: The Failure of a Dream?

Haller, Max , (New York and London: Routledge, 2008), 431 pp., ISBN 9780415403900

$\mathrm{H}$ ow do we go about studying elites, and especially intellectuals, in politics? This review highlights that while established sociological practices are in many ways adequate to the task, they can easily fall short of meeting Bourdieu's conception of sociology as a politics by other means - a sociology that unsettles and expands the parameters of political debate.

In some ways, Pierre Bourdieu's Political Interventions $(P I)$ and Max Haller's European Integration as an Elite Process (EIEP) are simply incomparable. $P I$ is a compilation of scholarly and political works for different kinds of audiences that both articulates a program for politically engaged sociology and offers a semiautobiographical model of it, written by a French sociologist who happens to be one of the most famous figures in the discipline. It offers, above all, lessons on sociological practice from an elite sociologist. EIEP, by contrast, is an application of sociology to the study of elites, a detailed and thoughtful analysis of their roles in European integration to date, with a less aggressively political (but certainly critical) tone. It was written by a German sociologist with a dignified European career, but who - like the rest of us does not occupy the same revered position as Bourdieu. Even if we set these obvious differences aside, the two books remain difficult to compare fairly because their content, style and tone undoubtedly express nationally and historically rooted differences in the practice and application of sociology, not to mention national variations in the discipline's prestige and anticipated audiences.

Still, there is a thread connecting the two works that should concern us all, and particularly those interested in the study 
of elites. Both books raise a crucial question: how should we analyze the role of elites in political life, keeping in mind that - if we adopt Bourdieu's perspective - we should count ourselves among their ranks? Stated differently, how do we analyze the intersection of elites and politics without being easily discredited as biased intellectuals who may also sit, now or in the future, at the very same intersection?

Perhaps, rather than trying to compare apples and oranges, we can consider both books as object lessons on how to deal with a wrinkle in our analytical gaze, doing a sociology of elites that is linked to a sociology of intellectuals including ourselves. What do these works tell us, explicitly or implicitly, about ironing out the wrinkle?

\section{LESSONS FROM AN ELITE SOCIOLOGIST}

[S]ociology aims at submitting actuality, as far as is possible, to the ordinary demands of scientific knowledge (Bourdieu, 1986, PI: pp. xvi-xvi).

PI documents Bourdieu's blend of theory and action by way of a time-ordered compilation of journal, magazine and news articles, interviews, speeches and policy reports. All told that the collection paints a vivid portrait of a committed public sociologist who acted on the political world using the tools of his trade; less obvious, but still there, are the ways in which he turned his experiences back onto the practice of sociology, seeking to foster the discipline's potential as 'a way of doing politics by other means' ( $P I$ : p.75). Indeed, for Bourdieu, sociology and politics were inseparable: 'two sides of a single work, one of analysis, deciphering and critique of social reality, with a view to assisting its transformation' ( $P I$ : xiv). Such a lofty view of sociology's transformative potential would perhaps 'how should we analyze the role of elites in political life, keeping in mind that - if we adopt Bourdieu's perspective we should count ourselves among their ranks?'

be easy to dismiss, except that Bourdieu was a living example of how it might be achieved.

Although PI offers no singular, summary statement on the wrinkle, its arraying of Bourdieu's various statements on the practice of sociology next to examples of his efforts to put sociology to work allows us to discern at least three lessons:

Lesson 1: (Re)Politicize. Bourdieu exhorts us, above all, to make 'a question out of what appears beyond question, self-evident - in a way that either arouses indignation, activist allegiance or rational conviction' (PI: $\mathrm{xv}-\mathrm{xvi}$ ). By making this first step - that is, turning what is taken for granted into something worth questioning - we use sociological analysis to expand the realm of political debate.

Lesson 2: Practice reflexivity. It is not enough to simply be aware of the biases of the scientific gaze; we must actively analyze the gap ... that separates the scholar and the dominated.' This is a not an option, but rather a 'scientific necessity' (PI: 5). Its elements include, first, giving up explicit and implicit claims to universalism:

[T] he myth of the intellectual and his or her universal mission is one of those ruses of historical reason that have given even those intellectuals most sensitive to the seductions and privileges of universality an interest in contributing, in the name of motivations that may have nothing universal 
about them, to the progress of true universality (PI: 28).

Second, reflexivity means analyzing the political effects of what we may otherwise consider tools of the trade or internal professional issues. This is clear, for instance, in Bourdieu's biting criticisms of political science and opinion polling, which he considered a 'science without scientists' that tends to exert (ironically) a depoliticizing effect (PI: 57-63):

The widespread practice of opinion polls has profoundly changed the operation of the political game: politicians now have to reckon with this new agency, largely controlled by political scientists, which is supposed to say - better than the 'representatives of the people' 'what people want and think' (PI: 62).

Another object of analysis Bourdieu specifies that might conventionally be considered a tool of the trade are systems of classification, which can be understood as ideologies that are 'the product of a field of specialized producers' that often include, among others, intellectuals (his primary example is a professor's grading system - PI: 67). Third and finally, reflexive sociology depends on broadening our notion of interest. Bourdieu highlights that classification systems generally originate from interested struggles among intellectuals (PI: 67). And yet intellectuals misunderstand themselves as disinterested, because 'we have an impoverished and economistic definition of interest' (PI: 65). Bourdieu tells us that '[t]he majority of things we call 'disinterested' ... are in actual fact interested, but in terms of a fuller definition of interest (PI: 65).

Lesson 3: Give 'voice to the voiceless' by challenging monopolistic forces in political life. In Bourdieu's view, intellectuals are in a unique position to break down barriers to political participation because, partly thanks to their
'In Bourdieu's view, intellectuals are in a unique position to break down barriers to political participation because, partly thanks to their educational credentials, they are licensed as politically competent'.

educational credentials, they are licensed as politically competent. They can use this privilege to challenge 'the division between the competent and the incompetent, amateurs and professionals,' which tends to be imposed not only by politicians 'but also journalists and a wider category of intellectuals' (PI: 70; see also 72-75).

Within this general theme Bourdieu emphasizes at least four practical principles. First, he tells us to remember that it takes intellectuals to challenge intellectuals. Here, Bourdieu highlights a problem that may be unique to the present age: 'old-style intellectuals, and philosophers above all' confront a ruling political elite that makes its own intellectual claims - that is, it legitimates itself based on intellectual competences and scientific credentials. This is a situation that can only be addressed by specifically intellectual challengers - which explains why, particularly toward the end of his life, Bourdieu put much effort into defending intellectual autonomy and mobilizing international intellectual activism ( $P I$ : 128; see also Chapters 7 and 8 ). The second, closely related, practical principle is to question 'economism' - that is, a narrow focus on the strictly economic consequences of policies, government and political action. This means recognizing, with a critical eye, the unique place of economics and economism as the

stephen lee mudge european political science: 82009 
backbone of modern technocratic government. Today's technocrat

... governs, deaf and blind, with his eyes fixed on economics textbooks sometimes even those he has written himself. His whole political philosophy is contained in his representation of economic information: information that lay people have to possess in order to comprehend, and thus accept, the economic decisions of professionals (PI: 71).

And so, hearteningly, Bourdieu tells us that there is political power in 'changing the representation of the social world, by giving imagination a bit of power' (PI: 73) and rethinking a world in which economics - rooted not just in neoclassicism and neoliberalism, but also Marxism - defines 'the universe of the conceivable' (PI: 108; see also 288-293).

Giving voice to the voiceless also means - and this is the third practical principle - rejecting the imposition of boundaries by political elites and media and, in the process, assuming no 'natural' political alliances. Sociologists should venture into the workings of political organizations - parties primary among them - and the media and question claims that 'politics belongs to them' (PI: 121-125). Along with this, Bourdieu's particularly aggressive critiques of the political left (e.g., 'The apparatchiks of the left have given us right for left', PI: 141), as well as his warning that intellectuals cannot control how they and their products are used in the 'political game' (PI: 147-152), signal his wariness of any unquestioned or stable alliances between intellectuals and politicians. We must neither take social problems as political elites and the media present them, nor (worse) invest ourselves in the maintenance of the reigning political common sense. Rather, sociologists should analyze the exclusive summits and 'meetings at the highest level' by which social '...by analyzing the processes by which meaning and knowledge are produced and are used to set boundaries on what is possible and what is not, we can show that there is nothing natural $[\ldots]$ about common sense'.

problems are produced, calling their very existence into question (PI: 74-75).

Last but not least, giving voice requires that we unmask definitional power, that is, question social reality itself by showing how 'social agents, and the dominated themselves, are bound into the social world ... by a relationship of complicity that makes certain aspects of this world lie always beyond the possibility of critical questioning' (PI: 133-134). Here, Bourdieu's key concept is 'symbolic power' - power that may be recognized as economic, political or cultural in nature, but that is also misrecognized as natural, rather than arbitrary. Stated differently, by analyzing the processes by which meaning and knowledge are produced and are used to set boundaries on what is possible and what is not, we can show that there is nothing natural - and certainly nothing inherently just - about common sense.

Beyond these three big lessons (politicization, reflexivity and giving voice to the voiceless), $P I$ also offers some specific methodological instructions: historicize not just actors, but the categories they use ('methodological historicization of the instruments of rational thought (categories of thought, principles of classification, concepts, etc. )'(PI: 223)); attend to the credentials and interests - economic 
or not - of actors (implying a biographical approach); refute the presentation of equations and statistics as truth (although he does not say that quantified data are never helpful). Taken together, we have a definite view of how (and for whom) political sociology should be done.

As to the wrinkle, Bourdieu tells us that there is no ironing it out; rather, we must make it an object of study, mapping its contours and uncovering its real and potential political effects. This is really a holistic statement on sociological practice, and not a guide to the methodological specifics of studying elites. In fact, the book tells us that studying elites is not enough; we must also look at the exclusionary effects of an elite-centric political world - that is, looking at the wrinkle from the outside-in by bringing social suffering and political disempowerment to light (PI: 185-187), and even participating in the fray ourselves by helping the politically marginalized articulate and advance their interests (PI: 271-274; 280-287; $362-363 ; 373)$. This brings us to the other work with which this review is concerned: a study of elites that considers the wrinkle from the inside out.

\section{LESSONS FROM A STUDY OF ELITES}

Max Haller's EIEP offers lessons on handling the wrinkle by way of example. Haller is concerned with the impasse to integration presented by the failure of the Constitution for Europe in 2005, focusing on the extent to which that impasse can be explained by a growing divide between European elites and European citizens in terms of benefits from, interests in and perspectives on integration (EIEP: $\mathbf{x x i}$ ). Citing a host of sociological traditions including a Weberian emphasis on the joint evaluation of ideas and interests and the critical study of knowledge rooted in the works of Mannheim (1970); Boudon (1986) and Camic and Gross (2004) -
Haller proposes to study Europe's impasse with emphasis on four kinds of issues: (1) the 'basic values and principles' that have guided the European project; (2) the institutional forms that integration has taken; (3) the integration-related interests of 'political, bureaucratic, professional and economic' elites; and (4) the general population's evaluation of integration in general and of Euroelites in particular (EIEP: xxii).

Embedded in Haller's framing of the problem is the notion that integration has social and political weaknesses that can and should by strengthened (EIEP: xxiv) - implying, it would seem, that the very elites Haller sets out to analyze are also his intended audience. If this interpretation is correct, then it is difficult to see how EIEP gives voice to the voiceless. In combination with a reliance on opinion surveys to deal with issue (4), EIEP is clearly inconsistent with a Bourdieusian sociology of elites.

Or is it? One cannot deny the value of pointing out to Euro-elites themselves that they are not, as many might claim, more or less naturally working in the general interest. Haller in fact strikes a highly critical tone simply by positing the interests of Euro-elites as an analytical question, rather than assuming either benevolence or a bland and neutral interest in advancing European integration. Consistent with Bourdieu's expanded notion of interest (a theme under Lesson 2: reflexivity), EIEP offers an enlightening look beyond the oft-noted interests of economic elites and the regressive elements of the EU's budget (EIEP, Chapter 4 - although Haller contends that there is no coherent 'power elite' or new Eurobusiness class, p. 122). It points out, for instance, the prestige interests of intellectuals and their resulting vulnerability to political cooptation (EIEP: 51, Chapter 7); the separate but related interests of the Commission-based 'Eurocracy', whose members have secured

stephen lee mudge european political science: 82009 
'considerable material privileges' by working as a force in integration's advance (EIEP: 44, Chapter 5); and the wide new field Europe offers for building or concluding a political career, created in part by historical figures who displayed, in Haller's estimation, clear autocratic and elitist inclinations (EIEP, Chapter 3, especially pp. 63-69 - note here, also, an attention to biography and history that is consistent with a Bourdieusian approach). Haller may accept the integration project as something that can and should be fixed, but his assertion that Europe's constitutional impasse is a consequence of various elites' failures and mishandlings that contribute, wittingly or unwittingly, to discouraging participation and privileging business and professional associations (EIEP: 56; 129) strikes a deeply politicizing tone.

As far as the use of statistics - setting aside, for now, opinion polls - this reviewer's impression is that they support EIEP's theme of a break between Euroelites and European publics in useful ways. Note, for instance, data on voter turnout and pro-European voting offered in Chapter 1, showing that national parliaments have been much more likely to vote pro-European than the general public (EIEP: 11) and, strikingly, that there is a fairly consistent negative relationship between voter turnout and voting proEuropean (EIEP: 14). Haller does not rest with statistical displays alone, pointing out (for example) that five of member states of the EU15 'inner circle' have never held referenda at all; three member states have only held them since 2005; and that France, whose political elites have arguably been the most invested in the European project since its beginnings, held its first referendum only in 1992.

As far as Bourdieu's dismissal of opinion polling as tending to silence the voices of dissenting minorities (the 'don't knows') or, perhaps worse, coercing people to express a definite position on questions

\section{'his assertion that Europe's constitutional impasse is a consequence of various elites' failures and mishandlings that contribute, wittingly or unwittingly, to discouraging participation and privileging business and professional associations [...] strikes a deeply politicizing tone'.}

they know nothing about and have never asked themselves, and then claiming special knowledge as to 'what the people want' - it is difficult to see how showing the very large amount of variability among European populations in their views on whether membership is a positive force and whether one's country has benefited from it, accounting also for selfestimations of general knowledge about what the EU is and how it works, serves the interests of any particular ruling elite (EIEP 208-214). Taken along with other interesting points - like that the EU's selfdesignation as 'a Community of values' makes dubious claims to a 'Christian character' and a 'European way of life' (EIEP: 241-247); that many European citizens are just as likely to attribute negative socioeconomic developments to the EU as positive ones (EIEP: 251, Figure $6.3)$; and that in the late 1980s (that is, the era of the Single Market Project and the 1987 Single European Act) citizens' view of European membership as a 'good thing' dropped noticeably (EIEP: 256, Figure 6.4) - the book assembles a strong cumulative case that Euro-politics 
are failing to give voice to the general population.

Which brings us, finally, to the question that is perhaps most central for a Bourdieusian approach to the wrinkle: the role of intellectuals and intellectual products in the politics of integration. Haller defines intellectuals, referencing Shils (1982), as

persons who are concerned with social developments and problems from rational and moral points of view and who try to win recognition and influence among the public and in politics with their publications and writings (EIEP: 264).

Again, the initial tone here is distinctly non-Bourdieusian; Haller's definition fails to take the 'intellectual' as a contested social category in the first place, and overlooks altogether the organization of intellectuals into disciplines and professions that have structures, histories and competitive dynamics of their own. Still, the central task that EIEP takes for itself is consistent, at least on its face, with Bourdieu's exhortation to uncover and identify the workings of symbolic or definitional power: 'to investigate how the public language and speaking, influenced mostly by political elites, determines what 'Europe' is or should be' - adding that 'elites want to give a kind of intellectual consecration or blessing to a political process which is guided to a large degree by mundane interests' (EIEP: 266). To this end, much of Chapter 7 is devoted to describing various prestigious thinkers' concepts of European integration and its goals, including Saint-Pierre's notion of a European federation for peace in the late seventeenth century, echoed by the philosophers Henri de SaintSimon, Johann Gottfried Herder and, in a different tone, Immanuel Kant (EIEP: 267-270; 276-280); as well as elitist and antidemocratic visions rooted in Friedrich Nietzsche's and others' works
'Highlighting the Kantian theme that peace is conditional on building democratic institutions, [Haller] questions whether European peace can really be credited to European integration'.

(EIEP: 271-276). Highlighting the Kantian theme that peace is conditional on building democratic institutions, EIEP questions whether European peace can really be credited to European integration, the extent to which integration has been a main source of democratization, and whether, in any case, peace and democracy would in fact be among Europe's central goals if the constitution were to pass (EIEP: 285-290; 294-298). Meanwhile, EIEP calls 'economism' to mind by pointing out that the constitution foregrounds economic freedom and competition (EIEP: 301-302), and that a coherent and critical intellectual voice on European integration is hard to find (EIEP: 305-312).

\section{A SOCIOLOGICAL POLITICS?}

What is the lesson here? Political sociologists and others interested in the study of elites might conclude that we need not adopt an unadulterated Bourdieusian approach as a precondition of dealing with the wrinkle; the classic works of mainstream sociology, particularly in the Weberian strain, are adequate to the task. On the other hand, EIEP's conclusions might prompt us to think again. After approaching the study of Euro-elites in a way that seems broadly consistent with Bourdieu's approach, we might expect EIEP to end with a call for Europe-wide

stephen lee mudge european political science: 82009 
social and intellectual mobilization that reopens political debate to the voiceless. Indeed, EIEP's contents amount to an overwhelming case against integration's forward march in a business-as-usual mode and for the radical overhaul of the elite-centric workings of European politics as a whole, perhaps built on a more fully developed supply of critical scholarship than presently exists. And yet the book concludes with a combination of institutional reform recommendations (EIEP: 342-351) and basic proposals to revitalize the constitution; it should be shortened, simplified and submitted to referenda on the same day in all the member states (EIEP: 351-359).

Here we find, at last, the root difference between the two works. Bourdieu's enduring theme was to think of sociology as politics by other means - remembering, always, that as part of the reflexive turn we cannot fail to rethink the possible and to try, as best we can, to constantly expand the terms of political contest. In short, Bourdieu's goal was not to inform politics as they are, but to imagine what they could be. And so, while EIEP offers a very useful model as a thoughtful and detailed study of elites - showing, in particular, that long-established sociological practices are in many ways adequate to the task - it is not a politics by other means. Whether sociology can or should aspire to fulfill the aims Bourdieu set for it, however, is another question.

\section{References}

Boudon, R. (1986) L'idéologie. L'origine des idées rescues, Paris: Librairie Arthème Fayard.

Camic, C. and Gross, N. (2004) 'The New Sociology of Ideas', in R. Blau Judith (ed.) The Blackwell Companion to Sociology, pp. 236-249, Malden, MA, Oxford and Carlton, UK: Blackwell.

Mannheim, K. (1970) Wissenssoziologie. Auswahl aus dem Werk, Neuwied, Germany and Berlin: Luchterhand.

\section{About the Author}

Stephanie Lee Mudge completed her Ph.D. in sociology at the University of California, Berkeley in 2007. She recently published in the Socio-Economic Review and is completing a manuscript on neoliberalism in mainstream politics. She joined the sociology faculty of the University of California, Davis, after postdoctoral work at the Max Planck Institute for the Study of Societies in Cologne, Germany. 